\title{
Clinical severity of human infections with avian influenza A(H7N9) virus, China, 2013/14
}

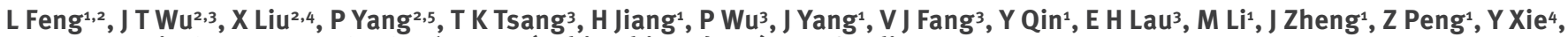

Q Wang ${ }^{5}$, Z Li ${ }^{1}$, G M Leung ${ }^{3}$, G F Gao ${ }^{6,7}$, H Yu (yuhj@chinacdc.cn) ${ }^{1}$, B J Cowling ${ }^{3}$

1. Division of Infectious Disease, Key Laboratory of Surveillance and Early-warning on Infectious Disease, Chinese Center for Disease Control and Prevention (China CDC), Beijing, China

2. These authors contributed equally to this work

3. School of Public Health, Li Ka Shing Faculty of Medicine, University of Hong Kong, Hong Kong Special Administrative Region, China

4. Jiangxi Provincial Centre for Disease Control and Prevention, Nanchang, Jiangxi Province, China

5. Beijing Center for Disease Prevention and Control; and Beijing Research Center for Preventive Medicine, Beijing, China

6. CAS Key Laboratory of Pathogenic Microbiology and Immunology, Institute of Microbiology, Chinese Academy of Sciences, Beijing, China

7. Office of Director-General, Chinese Center for Disease Control and Prevention (China CDC), Beijing, China

Citation style for this article:

Feng L, Wu JT, Liu X, Yang P, Tsang TK, Jiang H, Wu P, Yang J, Fang VJ, Qin Y, Lau EH, Li M, Zheng J, Peng Z, Xie Y, Wang Q, Li Z, Leung GM, Gao GF, Yu H, Cowling BJ. Clinical severity of human infections with avian influenza $A\left(\mathrm{H}_{7} \mathrm{~N} 9\right)$ virus, China, 2013/14. Euro Surveill. 2014;19(49):pii=20984. Available online: http://www. eurosurveillance.org/ViewArticle.aspx?Articleld=20984

Article submitted on 18 June 2014 / published on 11 December 2014

Assessing the severity of emerging infections is challenging because of potential biases in case ascertainment. The first human case of infection with influenza $\mathrm{A}\left(\mathrm{H}_{7} \mathrm{N9}\right)$ virus was identified in China in March 2013; since then, the virus has caused two epidemic waves in the country. There were 134 laboratory-confirmed cases detected in the first epidemic wave from January to September 2013. In the second epidemic wave of human infections with avian influenza $\mathrm{A}\left(\mathrm{H}_{7} \mathrm{~N} 9\right)$ virus in China from October 2013 to October 2014, we estimated that the risk of death among hospitalised cases of infection with influenza $\mathrm{A}\left(\mathrm{H}_{7} \mathrm{~N} 9\right)$ virus was $48 \%$ ( $95 \%$ credibility interval: $42-54 \%$ ), slightly higher than the corresponding risk in the first wave. Age-specific risks of death among hospitalised cases were also significantly higher in the second wave. Using data on symptomatic cases identified through national sentinel influenza-like illness surveillance, we estimated that the risk of death among symptomatic cases of infection with influenza $\mathrm{A}\left(\mathrm{H}_{7} \mathrm{~N} 9\right)$ virus was $0.10 \%(95 \%$ credibility interval: $0.029-3.6 \%$, which was similar to previous estimates for the first epidemic wave of human infections with influenza $\mathrm{A}\left(\mathrm{H}_{7} \mathrm{N9}\right)$ virus in 2013. An increase in the risk of death among hospitalised cases in the second wave could be real because of changes in the virus, because of seasonal changes in host susceptibility to severe infection, or because of variation in treatment practices between hospitals, while the increase could be artefactual because of changes in ascertainment of cases in different areas at different times.

\section{Introduction}

Since the first human case of infection with novel avian influenza $\mathrm{A}\left(\mathrm{H}_{7} \mathrm{~N} 9\right)$ virus was identified in China in March 2013, there have been two major epidemic waves of human infections to date. The first epidemic wave, in the spring of 2013, waned during the late spring and summer [1-3], while a second major epidemic wave occurred during the winter of 2013/14 and had waned by the end of the spring of 2014 while sporadic cases have continued to be reported (as of 9 October 2014). A small number of clusters of laboratory-confirmed cases have been identified in both epidemic waves, but the virus has not appeared to have the capacity for sustained human-to-human transmission [1].

Confirmed cases of infection with influenza $A\left(\mathrm{H}_{7} \mathrm{~N} 9\right)$ virus have generally been identified in hospitalised patients with pneumonia [4], however, a small number of confirmed cases was identified through routine sentinel influenza-like illness (ILI) surveillance which indicates the possibility for a larger number of mild influenza $A\left(\mathrm{H}_{7} \mathrm{~N}_{9}\right)$ virus infections $[5,6]$. This has implications for determination of the clinical severity of influenza $A\left(\mathrm{H}_{7} \mathrm{~N} 9\right)$ virus infections, because the confirmed cases may not fully reflect the clinical spectrum of infections, and consequently changes in case ascertainment could lead to artefactual variation in risk of severe outcomes.

In previous work, we demonstrated that the case fatality risk among confirmed cases of infection with the 2009 pandemic influenza $A\left(\mathrm{H}_{1} \mathrm{~N}_{1}\right)$ virus was very heterogeneous and difficult to interpret [7], and we characterised the severity of influenza $A\left(\mathrm{H}_{7} \mathrm{~N} 9\right)$ virus infections via the risk of fatalities among hospitalised cases (the 'hospitalisation fatality risk', HFR) and the risk of fatalities among symptomatic cases (the 'symptomatic case fatality risk', CFR) [3]. In the first epidemic wave of influenza $\mathrm{A}\left(\mathrm{H}_{7} \mathrm{~N} 9\right)$ virus infections in spring 2013, we estimated the HFR at $36 \%$, and the CFR at 
Incidence of laboratory-confirmed human cases of avian influenza A(H7N9) virus infection by date of hospitalisation, China, 1 February 2013-9 October 2014

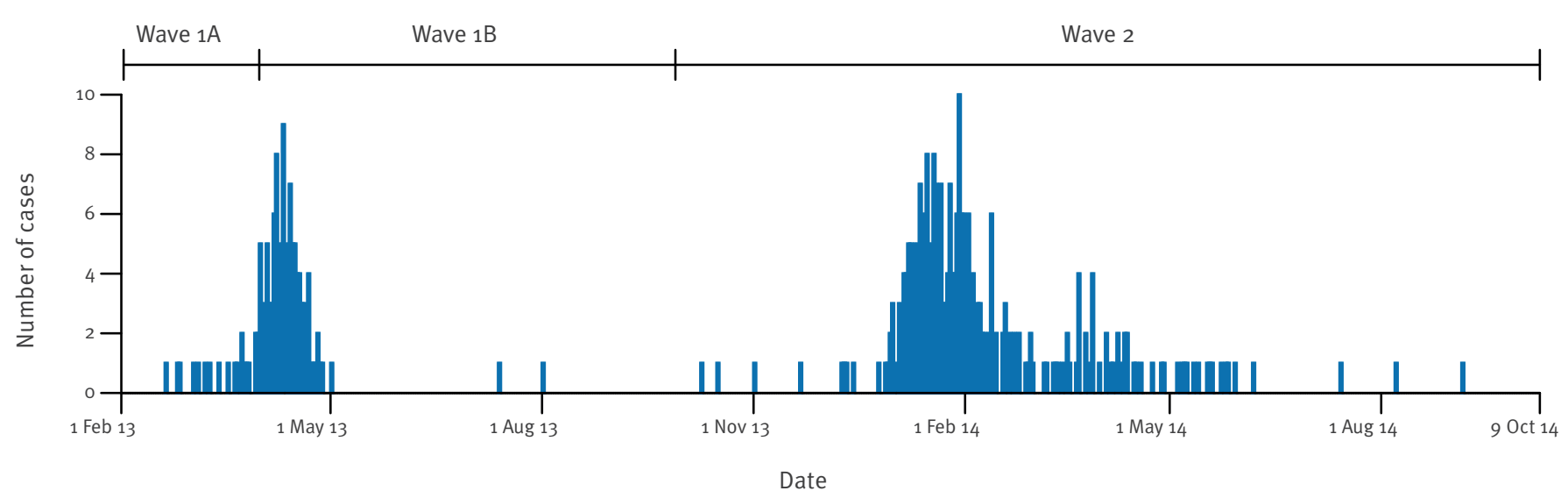

The first wave of infections in 2013 is divided into two parts, before and after the announcement of human cases on 31 March 2013 because of the potential for under-ascertainment of less severe cases in the earlier period.

$0.16 \%$ to $2.8 \%$ [3]. The objective of the present study is to estimate the HFR and symptomatic CFR in the second epidemic wave, and to determine whether the severity of human infections with influenza $A\left(\mathrm{H}_{7} \mathrm{~N} 9\right)$ virus has changed over time.

\section{Methods}

\section{Sources of data}

All laboratory-confirmed human cases of avian influenza $A\left(\mathrm{H}_{7} \mathrm{~N}\right.$ 9) virus infection are reported to the Chinese Center for Disease Control and Prevention (China CDC) through a national surveillance system. Case definitions, surveillance for identification of cases, and laboratory assays have been previously described [1]. Demographic, epidemiological, and basic clinical data were obtained from each confirmed case with standardised forms. An integrated database was constructed by China CDC, with detailed epidemiological information about each confirmed case of infection with influenza $\mathrm{A}\left(\mathrm{H}_{7} \mathrm{~N} 9\right)$ virus reported by 9 October 2014. We used information about age, sex, place of residence, dates of illness onset, hospital admission, intensive care unit (ICU) admission, mechanical ventilation, death, and recovery or discharge.

\section{Statistical analysis}

Cases were determined to be hospitalised for medical reasons (rather than solely for isolation purposes) based on routine clinical judgment, e.g. those presenting with complications such as pneumonia. A small number of cases presenting with mild respiratory symptoms did not have any complications throughout the clinical course and were hospitalised only for the purpose of isolation. Among the confirmed cases of influenza $A\left(\mathrm{H}_{7} \mathrm{~N} 9\right)$ virus infection that were hospitalised for medical reasons, i.e. excluding these mild cases, we estimated the risks of ICU admission, mechanical ventilation, and death. To allow for the uncertain outcomes of cases that remained in hospital on the date of analysis (9 October 2014), we used the method proposed by Garske et al., which inflates the observed fatality risk based on the time to death distribution [8]. We constructed $95 \%$ confidence intervals (CIs) using a bootstrap approach with 1,000 resamples.

To estimate the symptomatic CFR, we inferred the number of symptomatic cases based on the detection of symptomatic cases through sentinel ILI surveillance in urban areas [3]. We searched for urban areas where (i) the number of confirmed $\mathrm{A}\left(\mathrm{H}_{7} \mathrm{~N} 9\right)$ virus infection cases registered by local ILI sentinels and other hospitals are both larger than one, and (ii) the number of outpatient visits at local ILI sentinels and other hospitals is available. In the spring 2013 epidemic wave, Shanghai and Nanjing (Jiangsu province) met the criteria, and in the winter 2013/14 epidemic wave the city of Shaoxing (Zhejiang province) met the criteria. In these selected urban areas, we determined the daily number of all ILI cases reported and specimens tested by ILI surveillance in each location during the relevant period to infer the number of infected individuals who would have sought medical care at ILI sentinels $\left(\mathrm{N}_{\mathrm{ILI}}\right)$. We assumed that healthcare seeking behaviour of individuals with ILI associated with influenza $\mathrm{A}\left(\mathrm{H}_{7} \mathrm{~N} 9\right)$ virus infection was the same as healthcare seeking behaviour of individuals with ILI associated with 2009 pandemic influenza $A\left(\mathrm{H}_{1} \mathrm{~N}_{1}\right)$ virus infection in $2009 / 10$ in the same area of China. We used data from a nationwide serosurvey and ILI surveillance of the 2009 influenza $A\left(\mathrm{H}_{1} \mathrm{~N}_{1}\right)$ pandemic in China from June 2009 to January 2010, to estimate the proportion of individuals with symptomatic infections who sought medical care at ILI sentinels. We divided $\mathrm{N}_{\mathrm{ILI}}$ by this proportion. We then estimated the symptomatic CFR in each location using the number of confirmed deaths as the numerator and the estimated 
Estimates and 95\% credibility intervals of the risk of serious outcomes among laboratory-confirmed human cases of avian influenza A(H7N9) hospitalised for medical reasons, by age and wave, China, 1 February 2013-9 October 2014

A

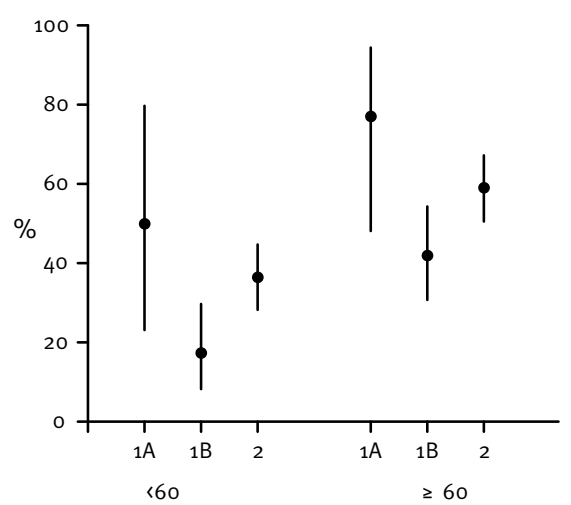

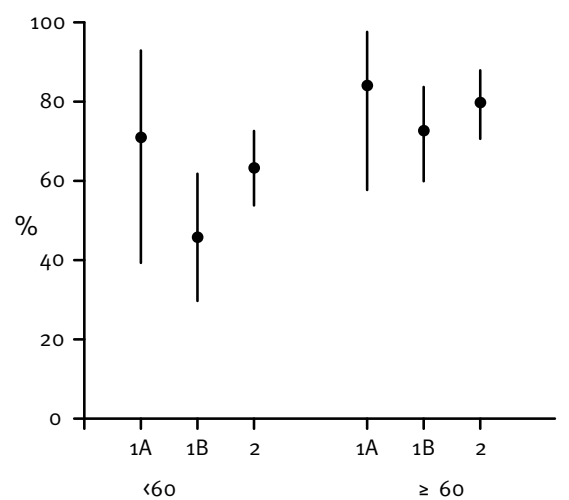

C

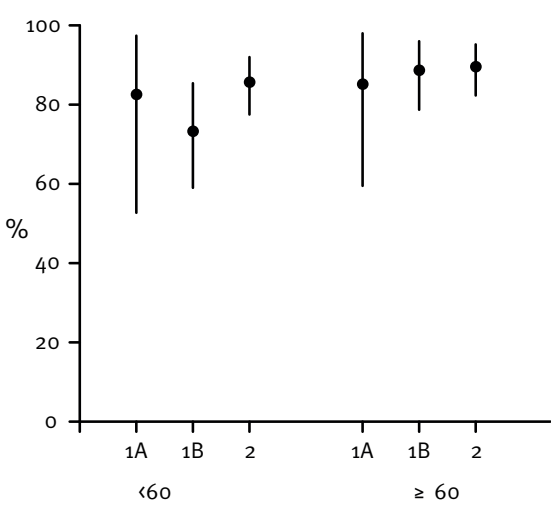

Age (years)

Panel A: the risk of death. Panel B: the risk of death or mechanical ventilation. Panel C: the risk of death or mechanical ventilation or intensive care unit admission.

Epidemic wave 1A: 1 February-31 March 2013

Epidemic wave 1B: 1 April-30 September 2013

Epidemic wave 2: 1 October 2013-9 October 2014

number of mild cases as the denominator. We used a Bayesian framework to estimate the symptomatic CFR, and presented the estimates with $95 \%$ credibility intervals (Crl) which have a similar interpretation to confidence intervals [9].

We examined epidemiologic time-to-event distributions using kernel density methods as previously described [2]. All statistical analyses were performed using $R$ version 3.0.1 (R Foundation for Statistical Computing, Vienna, Austria) and Matlab (Mathworks Inc., Natick, Massachusetts, United States).

\section{Results}

In the first wave of influenza $\mathrm{A}\left(\mathrm{H}_{7} \mathrm{~N} 9\right)$ cases in 2013 , 134 confirmed cases were identified (Figure 1), of whom 124 required hospitalisation for medical reasons.

Among the hospitalised cases, the risk of serious outcomes was higher among older hospitalised cases. Furthermore, we identified higher risks of fatalities among cases hospitalised before 31 March 2013, the date when the first confirmed human cases of influenza $\mathrm{A}\left(\mathrm{H}_{7} \mathrm{~N} 9\right)$ virus infection were officially announced in China (Figure 2).

We therefore divided the first wave into two parts: wave $1 \mathrm{~A}$ for 18 cases hospitalised before 1 April 2013, and wave $1 \mathrm{~B}$ for 106 cases hospitalised from 1 April to 30 September 2013 (Figure 1).

In the first epidemic wave, the median age was 60 years in wave $1 \mathrm{~A}$ and 61 years in wave $1 \mathrm{~B}$. Among the cases under 60 years who required hospitalisation for medical reasons, the HFR in wave $1 \mathrm{~A}$ was $51 \%(95 \% \mathrm{Cl}$ : $21 \%-79 \%)$, significantly higher $(\mathrm{p}=0.039)$ than the HFR of $17 \%(95 \% \mathrm{Cl}: 7.6 \%-30 \%)$ in wave $1 \mathrm{~B}$. For cases above 60 years who required hospitalisation for medical reasons, the HFR was also significantly higher $(p=0.025)$ in wave $1 \mathrm{~A}(77 \% ; 95 \% \mathrm{Cl}: 48 \%-94 \%)$ vs wave $1 \mathrm{~B}(42 \%$, $95 \% \mathrm{Cl}: 31 \%-54 \%)$. We did not identify significant differences between wave $1 \mathrm{~A}$ and $1 \mathrm{~B}$ in the risk of death or ventilation, or in the risk of death/ventilation/ICU admission (Figure 2).

In the second epidemic wave of influenza $\mathrm{A}\left(\mathrm{H}_{7} \mathrm{~N} 9\right), 273$ of the 306 confirmed cases required hospitalisation for medical reasons with onset dates between 1 October 2013 and 9 October 2014. The median age was 57 years (range 2-88 years). Sixty-nine percent of cases were male. Among the hospitalised cases, allowing for censoring of outcomes in five $(2 \%)$ patients remain in hospital on 9 October 2014 , we estimated HFRs of $36 \%$ (95\% Cl: $28 \%-45 \%$ ) in cases under 60 years, and $59 \%$ (95\% Cl: $51 \%-67 \%$ ) in cases aged 60 years or above. These risks were significantly higher than in wave $1 \mathrm{~B}$ $(p=0.019$ and $p=0.025$ respectively). There were no statistically significant differences between the agespecific risks of death or ventilation, or death/ventilation/ICU admission in wave 2 compared to either wave $1 \mathrm{~A}$ or wave $1 \mathrm{~B}$, while estimates of the risks of serious outcomes were generally lower across age groups in wave $1 \mathrm{~B}$ compared with wave 2 (Figure 2 ). While the second epidemic wave occurred over a broader geographic area than the first wave, Zhejiang province was heavily affected in both epidemic waves. We 


\section{FIGURE 3}

Comparisons of epidemiologic distributions between waves, human cases of avian influenza A(H7N9), China, 1 February 2013-9 October 2014

A Days from illness onset to hospital admission

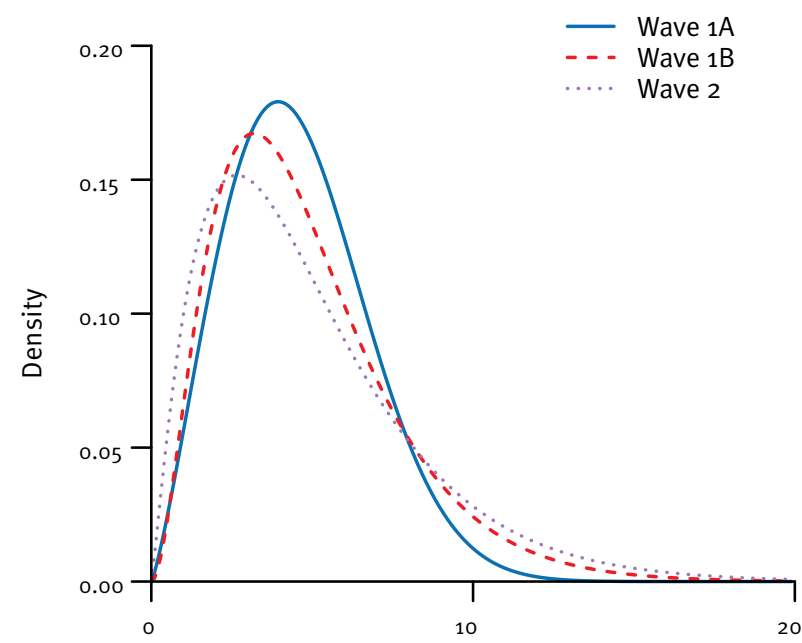

C Days from hospital admission to death

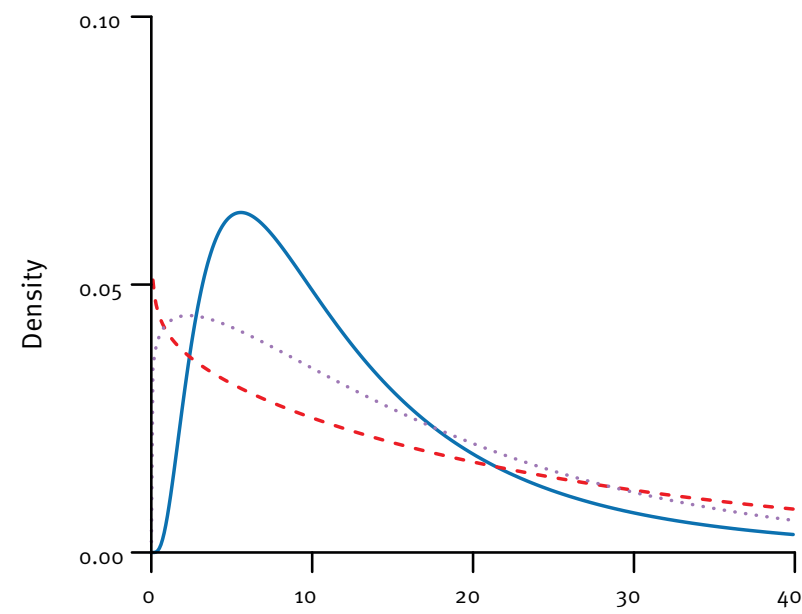

Wave 1A: 1 February-31 March 2013

Wave 1B: 1 April-30 September 2013

Wave 2: 1 October 2013-9 October 2014

therefore examined the risk of death among the subset of hospitalised cases in this province. Zhejiang province reported 40 cases in wave $1 \mathrm{~B}$ and 88 cases in wave 2, and the risk of death among hospitalised casesunder 60 years-old was significantly higher in wave 2 compared with wave $1 \mathrm{~B}$ (risk ratio $7.1 ; 95 \% \mathrm{Cl}$ : 1.3-292; $p=0.017$ ) and not significantly different in hospitalised casesabove 60 years-old (risk ratio 1.5; 95\% Cl: 0.93-2.8; $p=0.099$ ).

We examined the delays from onset to admission and identified similar patterns over calendar time, while the delay from onset to laboratory confirmation has shortened over time and in wave 2 the mean was eight days (Figure 3). Distributions of time from admission
B Days from illness onset to confirmation

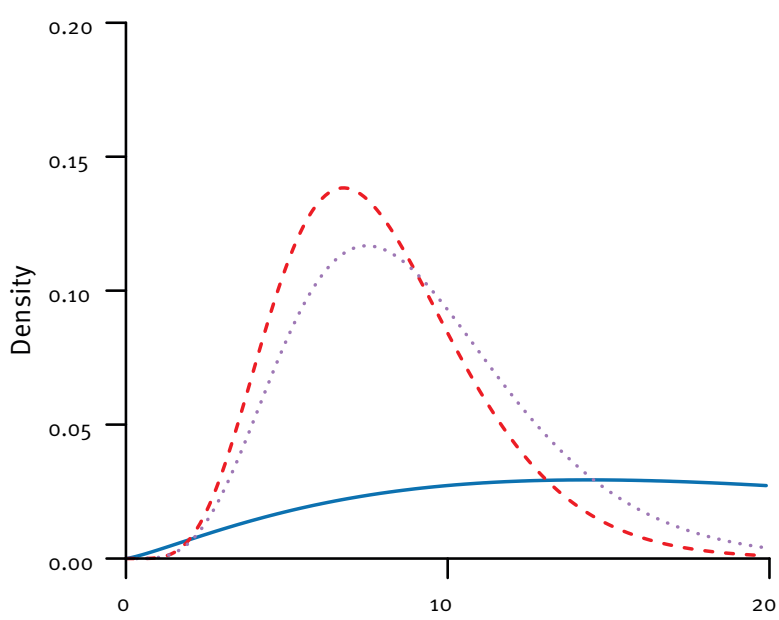

D Days from hospital admission to discharge

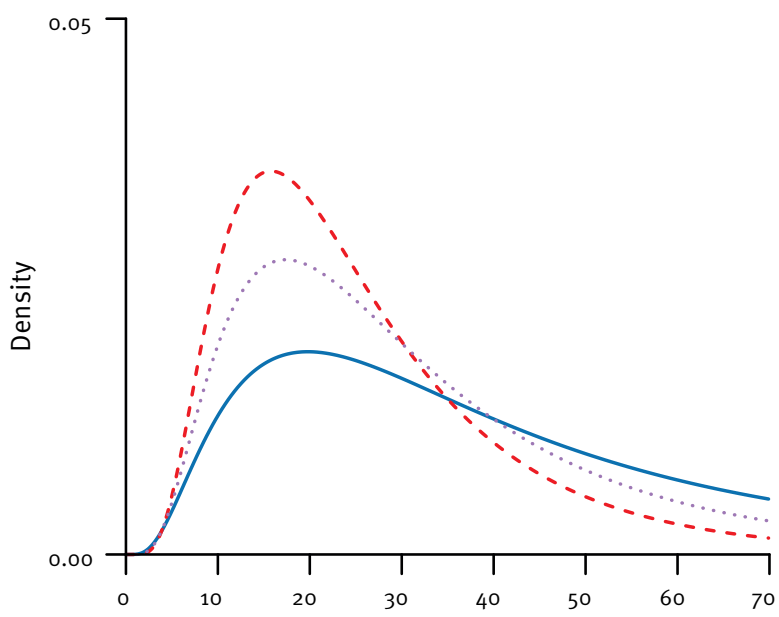

to death and from admission to discharge were similar over time (Figure 3).

We previously used information on three confirmed influenza $\mathrm{A}\left(\mathrm{H}_{7} \mathrm{~N}\right.$ ) cases identified through ILI surveillance in Shanghai and Nanjing to estimate the number of symptomatic cases in the spring 2013 epidemic wave [3]. Here we also use information on four confirmed cases identified through ILI surveillance in Shaoxing in the winter 2013/14 epidemic wave, in the period from 1 January to 21 January 2014, before the closure of live poultry markets on 22 January. During the same period in Shaoxing, nine hospitalised cases had onset of illness, of whom five died. Based on these observations, we estimated that there were 3,020 
Estimates of the symptomatic case fatality risk, human cases of influenza A(H7N9) virus infection, China, 1 January 2013-21 January 2014

\begin{tabular}{|l|c|c|c|c|}
\hline Period analysed & Geographic location & $\begin{array}{c}\text { Number of } \\
\text { confirmed } \\
\text { deaths caused by } \\
\text { influenza A(H7Ng) } \\
\text { virus infection }\end{array}$ & $\begin{array}{c}\text { Estimated number of } \\
\text { symptomatic A(H7N9) virus } \\
\text { infections }\end{array}$ & $\begin{array}{c}\text { Estimated risk of fatalities per } \\
100,000 \text { symptomatic cases }\end{array}$ \\
\hline 1 Jan 2013-28 May 2013 & Shanghai & 14 & $3,020(95 \% \mathrm{Cl}: 900-7,800)$ & $490(95 \% \mathrm{Cl}: 170-1,800)$ \\
\hline 1 Jan 2013-28 May 2013 & Nanjing (Jiangsu province) & 3 & $5,310(95 \% \mathrm{Cl}: 880-17,300)$ & $69(95 \% \mathrm{Cl}: 12-710)$ \\
\hline & & 5 & $5,750(95 \% \mathrm{Cl}: 1,960-12,730)$ & $100(95 \% \mathrm{Cl}: 29-360)$ \\
\hline 1 Jan 2014-21 Jan 2014 & Shaoxing (Zhejiang province) & 5 & & \\
\hline
\end{tabular}

$\mathrm{Cl}$ : confidence interval.

(95\% Cl: $900-7,800)$ and 5,310 (95\% Cl: 880-17,300) cases in the first epidemic wave in 2013 in Shanghai and Nanjing, respectively, and 5,750 (95\% Cl: $1,960-$ 12,730) cases in Shaoxing in the second epidemic wave in $2013 / 14$. These estimates correspond to symptomatic CFRs of 490 and 69 in Shanghai and Nanjing respectively in the first wave, and 100 per 100,000 symptomatic cases in Shaoxing in the second wave, with wide and overlapping credibility intervals (Table).

\section{Discussion}

The resurgence of human infections with avian influenza $A\left(\mathrm{H}_{7} \mathrm{~N}\right.$ 9) virus in a second epidemic wave in 2013/14 demonstrates the continued public health risk of this novel strain [10]. Control of the virus in animals is complicated, because the infections in poultry are asymptomatic [11]. Human-to-human transmissibility of the virus remains limited, as evidenced by the very small number of potential secondary infections identified through detailed contact tracing of confirmed cases $[1,2,12-14]$.

We identified differences in the severity of illness of hospitalised cases in the earlier part of the first epidemic wave in 2013, with greater risk of mechanical ventilation, ICU admission and death among cases hospitalised before 31 March 2013 when the first confirmed human cases of influenza $A\left(\mathrm{H}_{7} \mathrm{~N} 9\right)$ were officially announced (Figure 2) [15]. One explanation for this is more timely antiviral treatment and more appropriate supportive care for cases hospitalised after 31 March 2013. Another possible explanation is detection bias in the early phase of the spring 2013 epidemic wave, where more severe cases were prioritised for repeated laboratory testing, and cases with prolonged virus shedding or higher virus shedding had a greater chance of confirmation.

In the second epidemic wave in $2013 / 14$, we identified a significantly greater HFR compared with the latter part of the first epidemic wave in 2013 (Figure 2) and in persons under 60 years of age in Zhejiang province where cases occurred in both epidemic waves, but no difference in the symptomatic CFR (Table). It is possible that this significant difference in HFRs is due to ascertainment bias in cases in different locations at different times, even within the same province. Alternatively, the HFR could have increased, because hospitalised cases in the second epidemic wave in 2013/14 were less likely to be transferred to larger referral hospitals ( $\mathrm{Dr}$ Enfu Chen, Chief Epidemiologist in Zhejiang Provincial CDC, personal communication, June 2014), because of changes in the virus, or because of seasonal changes in the prevalence of other pathogens that could cause secondary or co-infections and modify the severity of influenza $A\left(\mathrm{H}_{7} \mathrm{~N} 9\right)$ virus infections [16]. Whereas ascertainment of infections in hospitalised cases may have changed over time due to changes in awareness and testing capacity, the ascertainment of influenza $\mathrm{A}\left(\mathrm{H}_{7} \mathrm{~N} 9\right)$ cases through the established sentinel ILI network should have remained more stable over time.

Large population-based serological studies in affected areas would permit assessment of severity with a denominator of infections, rather than cases of symptomatic disease or hospitalisation, and infection-based severity measures could be less susceptible to biases due to differential healthcare seeking behaviours or diagnostic capacity $[3,7]$. To date, few serological studies have been reported and such analyses are not yet possible [17-19].

Our estimates of the risks of serious outcomes in hospitalised cases are limited by the potential for under-ascertainment of cases, due to lack of access to laboratory testing in some areas, and the potential for imperfect sensitivity of laboratory testing for the $A\left(\mathrm{H}_{7} \mathrm{~N} 9\right)$ virus $[20,21]$. While we accounted for unknown final status of cases that remain hospitalised in our analysis, the eventual estimates may change slightly once all outcomes are known. It is challenging to estimate the symptomatic CFR based on a small number of confirmed cases with milder disease identified through sentinel ILI surveillance, and our estimates are dependent on the assumptions that coverage of the sentinel system was similar in 2013/14 compared with 2009, and that healthcare seeking behaviours for ILI were similar whether illness was caused by influenza 
$A\left(\mathrm{H}_{7} \mathrm{~N}_{9}\right)$ virus or the 2009 pandemic influenza $A\left(\mathrm{H}_{1} \mathrm{~N}_{1}\right)$ virus [3]. In addition, the estimation of SCFR were based on data from geographic locations in which influenza $\mathrm{A}(\mathrm{H} 7 \mathrm{~N}$ 9) virus infections were identified through sentinel ILI surveillance, and a more comprehensive analysis could also incorporate data on ILI surveillance in other areas.

In conclusion, it remains important to assess the severity of human infections with influenza $A\left(\mathrm{H}_{7} \mathrm{~N} 9\right)$ virus, as part of ongoing risk assessment of this virus. While the overall picture is that the severity of human infections has not substantially changed (Table), we found some evidence that the HFR was higher in the second epidemic wave in 2013/14 (Figure 2). Our results again highlight that many influenza $\mathrm{A}\left(\mathrm{H}_{7} \mathrm{~N} 9\right)$ virus infections can cause mild disease [3,5,6] and that the risk of death among laboratory-confirmed cases is a misleading measure of severity. If another epidemic of human infections with influenza $\mathrm{A}\left(\mathrm{H}_{7} \mathrm{~N} 9\right)$ virus occurs in the winter of 2014/15, proactive control measures on the poultry-human interface may be preferable to reactive measures [10,22-24]. Comprehensive surveillance of avian influenza virus infections in animals and humans is essential in order to monitor risk and guide the use of control measures.

\section{Acknowledgements}

We thank staff members at county-, district-, prefecture-, and provincial- level CDCs at the provinces where human cases of influenza $A\left(\mathrm{H}_{7} \mathrm{~N} 9\right)$ virus infection occurred for providing assistance with field investigation, administration and data collection.

This study was funded by the United States National Institutes of Health (Comprehensive International Program for Research on AIDS grant U19 Al51915), the China-United States Collaborative Program on Emerging and Re-emerging Infectious Diseases, grants from the Ministry of Science and Technology, China (2012 ZX10004-201), the Harvard Center for Communicable Disease Dynamics from the National Institute of General Medical Sciences (grant no. U54 GMo88558), the Area of Excellence Scheme of the Hong Kong University Grants Committee (grant no. AoE/M-12/06), and the Beijing Science and Technology Planning Project of Beijing Science and Technology Commission (Z131100005613048). The funding bodies had no role in study design, data collection and analysis, preparation of the manuscript, or the decision to publish.

\section{Conflicts of interest}

GML has received consulting honoraria from Janssen Pharmaceuticals. BJC reports receipt of research funding from MedImmune Inc. and Sanofi Pasteur, and consults for Crucell NV.

\section{Authors' contributions}

Hongjie $\mathrm{Yu}$ and Benjamin J Cowling designed the study. Luzhao Feng, Joseph T. Wu, Xiaoqing Liu, Peng Yang, Tim K. Tsang, Hui Jiang, Peng Wu, Juan Yang, Vicky J. Fang, Ying Qin, Eric H. Y. Lau, Ming Li, Jiandong Zheng, Zhibin Peng, Yun Xie, Quanyi Wang, Zhongjie Li, Gabriel M. Leung and George F. Gao collected data. Luzhao Feng, Joseph T. Wu, Tim K. Tsang,
Peng Wu, Vicky J. Fang and Eric H. Y. Lau analysed data. Benjamin J Cowling wrote the first draft and all authors contributed to review and revision and have seen and approved the final version.

\section{References}

1. Li Q, Zhou L, Zhou M, Chen Z, Li F, Wu H, et al. Epidemiology of human infections with avian influenza $\mathrm{A}(\mathrm{H} 7 \mathrm{Ng})$ virus in China. N Engl J Med. 2014;370(6):520-32. http://dx.doi.org/10.1056/ NEJMoa1304617 PMID:23614499

2. Cowling BJ, Jin L, Lau EH, Liao Q, Wu P, Jiang H, et al. Comparative epidemiology of human infections with avian influenza $\mathrm{A} \mathrm{H}_{7} \mathrm{~N}_{9}$ and $\mathrm{H}_{5} \mathrm{~N}_{1}$ viruses in China: a populationbased study of laboratory-confirmed cases. Lancet. 2013;382(9887):129-37. http://dx.doi.org/10.1016/S01406736(13)61171-X PMID:23803488

3. Yu H, Cowling BJ, Feng L, Lau EH, Liao Q, Tsang TK, et al. Human infection with avian influenza $\mathrm{A} H 7 \mathrm{~N} 9$ virus: an assessment of clinical severity. Lancet. 2013;382(9887):13845. http://dx.doi.org/10.1016/S0140-6736(13)61207-6 PMID:23803487

4. Xiang N, Havers F, Chen T, Song Y, Tu W, Li L, et al. Use of national pneumonia surveillance to describe influenza $A\left(\mathrm{H}_{7} \mathrm{~N} 9\right)$ virus epidemiology, China, 2004-2013. Emerg Infect Dis. 2013;19(11):1784-90. http://dx.doi.org/10.3201/eid1911.130865 PMID:24206646

5. Ip DK, Liao Q, Wu P, Gao Z, Cao B, Feng L, et al. Detection of mild to moderate influenza $A / \mathrm{H} 7 \mathrm{~N}$ g infection by China's national sentinel surveillance system for influenza-like illness: case series. BM). 2013;346(jun24 1):f3693. http://dx.doi. org/10.1136/bmj.f3693 PMID:23798720

6. Xu C, Havers F, Wang L, Chen T, Shi J, Wang D, et al. Monitoring avian influenza $A(H 7 \mathrm{~N} 9)$ virus through national influenza-like illness surveillance, China. Emerg Infect Dis. 2013;19(8):1289. 92. http://dx.doi.org/10.3201/eid1907.130662 PMID:23879887

7. Wong JY, Kelly H, Ip DK, Wu JT, Leung GM, Cowling BJ. Case fatality risk of influenza $A$ ( $\left.\mathrm{H}_{1} \mathrm{~N}_{1} \mathrm{pdmog}\right)$ : a systematic review. Epidemiology. 2013;24(6):830-41. http://dx.doi.org/10.1097/ EDE.ob013e3182a67448 PMID:24045719

8. Garske T, Legrand J, Donnelly CA, Ward H, Cauchemez S, Fraser C, et al. Assessing the severity of the novel influenza A/ H1N1 pandemic. BMJ. 2009;339(jul14 3):b2840. http://dx.doi. org/10.1136/bmj.b2840 PMID:19602714

9. Sterne JA, Davey Smith G. Sifting the evidence-what's wrong with significance tests? BMJ. 2001;322(7280):226-31. http:// dx.doi.org/10.1136/bmj.322.7280.226 PMID:11159626

10. Gilbert M, Golding N, Zhou H, Wint GR, Robinson TP, Tatem AJ, et al. Predicting the risk of avian influenza $\mathrm{A} \mathrm{H} 7 \mathrm{~N} 9$ infection in live-poultry markets across Asia. Nat Commun. 2014;5:4116. http://dx.doi.org/10.1038/ncomms5116 PMID:24937647

11. Uyeki TM, Cox NJ. Global concerns regarding novel influenza A (H7N9) virus infections. N Engl J Med. 2013;368(20):1862-4. http://dx.doi.org/10.1056/NEJMp1304661 PMID:23577629

12. Hu J, Zhu Y, Zhao B, Li J, Liu L, Gu K, et al. Limited humanto-human transmission of avian influenza $A(\mathrm{H} 7 \mathrm{Ng})$ virus, Shanghai, China, March to April 2013. Euro Surveill. 2014;19(25):20838. http://dx.doi.org/10.2807/1560-7917. ES2014.19.25.20838 PMID:24993556

13. Qi X, Qian YH, Bao CJ, Guo XL, Cui LB, Tang FY, et al. Probable person to person transmission of novel avian influenza $A(\mathrm{H} 7 \mathrm{~N} 9)$ virus in Eastern China, 2013: epidemiological investigation. BMJ. 2013;347(augo6 2):f4752. http://dx.doi. org/10.1136/bmj.f4752 PMID:23920350

14. Yi L, Guan D, Kang M, Wu J, Zeng X, Lu J, et al. Family Clusters of Avian Influenza A H7No Infection in Guangdong Province, China. J Clin Microbiol. 2014 Oct 22. pii: JCM.02322-14. [Epub ahead of print]. http://dx.doi.org/10.1128/JCM.02322-14 PMID:25339399

15. Gao R, Cao B, Hu Y, Feng Z, Wang D, Hu W, et al. Human infection with a novel avian-origin influenza $A\left(\mathrm{H}_{7} \mathrm{~N} 9\right)$ virus. $\mathrm{N}$ Engl J Med. 2013;368(20):1888-97. http://dx.doi.org/10.1056/ NEJMoa1304459 PMID:23577628

16. Hament JM, Kimpen JL, Fleer A, Wolfs TF. Respiratory viral infection predisposing for bacterial disease: a concise review. FEMS Immunol Med Microbiol. 1999;26(3-4):189-95. http:// dx.doi.org/10.1111/j.1574-695X.1999.tb01389.x PMID:10575129

17. Wang X, Fang S, Lu X, Xu C, Cowling BJ, Tang X, et al. Seroprevalence to avian influenza $A(H 7 N 9)$ virus among poultry workers and the general population in southern China: a longitudinal study. Clin Infect Dis. 2014;59(6):e76-83. http:// dx.doi.org/10.1093/cid/ciu399 PMID:24867786 
18. Bai T, Zhou J, Shu Y. Serologic study for influenza A $(\mathrm{H} 7 \mathrm{Ng})$ among high-risk groups in China. N Engl J Med. 2013;368(24):2339-40. http://dx.doi.org/10.1056/ NEJMC1305865 PMID:23718151

19. Yang S, Chen Y, Cui D, Yao H, Lou J, Huo Z, et al. Avian-origin influenza $A\left(\mathrm{H}_{7} \mathrm{~N} 9\right)$ infection in influenza $A\left(\mathrm{H}_{7} \mathrm{~N} 9\right)$-affected areas of China: a serological study. J Infect Dis. 2014;209(2):265-9. http://dx.doi.org/10.1093/infdis/jit430 PMID:23935201

20. Chen Y, Liang W, Yang S, Wu N, Gao H, Sheng J, et al. Human infections with the emerging avian influenza $\mathrm{A} \mathrm{H}_{7} \mathrm{~N}$ g virus from wet market poultry: clinical analysis and characterisation of viral genome. Lancet. 2013;381(9881):1916-25. http://dx.doi. org/10.1016/S0140-6736(13)60903-4 PMID:23623390

21. Hu Y, Lu S, Song Z, Wang W, Hao P, Li J, et al. Association between adverse clinical outcome in human disease caused by novel influenza $\mathrm{A} \mathrm{H}_{7} \mathrm{~N} 9$ virus and sustained viral shedding and emergence of antiviral resistance. Lancet. 2013;381(9885):2273-9. http://dx.doi.org/10.1016/S01406736(13)61125-3 PMID:23726392

22. Yu H, Wu JT, Cowling BJ, Liao Q, Fang VJ, Zhou S, et al. Effect of closure of live poultry markets on poultry-toperson transmission of avian influenza $\mathrm{A} \mathrm{H} \mathrm{H}^{\mathrm{N}}$ 9 virus: an ecological study. Lancet. 2014;383(9916):541-8. http://dx.doi. org/10.1016/S0140-6736(13)61904-2 PMID:24183056

23. Wu P, Jiang H, Wu JT, Chen E, He J, Zhou H, et al. Poultry market closures and human infection with influenza $A\left(\mathrm{H}_{7} \mathrm{Ng}\right)$ virus, China, 2013-14. Emerg Infect Dis. 2014;20(11):1891-4. http:// dx.doi.org/10.3201/eid2011.140556 PMID:25340354

24. Fournié G, Pfeiffer DU. Can closure of live poultry markets halt the spread of $\mathrm{H} 7 \mathrm{~N} 9$ ? Lancet. 2014;383(9916):496-7. http:// dx.doi.org/10.1016/S0140-6736(13)62109-1 PMID:24183055 